\title{
A Case of Liposarcoma Arising in Tracheoesophageal Groove
}

\author{
Jae Min Hong, Do Yang Park, Sung Mi Kang and Yoon Woo Koh \\ Department of Otorhinolaryngology, Yonsei University College of Medicine, Seoul, Korea
}

\section{기관식도구에 발생한 지방육종 1 예}

홍재민 · 박도양 - 강성미 · 고윤우

연세대학교 의과대학 이비인후과학교실

Received September 6, 2010

Revised November 24, 2010

Accepted November 30, 2010

Address for correspondence

Yoon Woo Koh, MD, PhD

Department of Otorhinolaryngology,

Yonsei University

College of Medicine,

250 Seongsan-ro, Seodaemun-gu,

Seoul 120-752, Korea

Tel +82-2-2228-3607

Fax +82-2-393-0580

E-mail ywkohent@yuhs.ac
Liposarcoma is the second most common soft tissue sarcoma in adult, after malignant fibrous histiocytoma. But, the incidence of liposarcoma in the head and neck malignancies is approximately $1.8-6.3 \%$. Primary liposarcoma of the thyroid gland is exceedingly rare with only six previous reports in the English literature. We report a case of liposarcoma in a 61-yearold male who had been misdiagnosed with thyroid nodule and follicular neoplasm suspected in fine needle aspiration cytology. Mass excision of the liposarcoma was performed. During the preoperative evaluation and operation, the author recognized that the tumor had originated not from the thyroid gland, but from the tracheoesophageal groove. The histopathological examination revealed a combination type liposarcoma that was both well differentiated and myxoid. But a paramedian fixation was found in the left vocal cord palsy and injection laryngoplasty was performed. Postoperatively, radiotherapy was given to the neck region. During the 36-month follow-up period, there was no evidence of the disease.

Korean J Otorhinolaryngol-Head Neck Surg 2011;54:170-3

Key Words Liposarcoma Thyroid nodule.

\section{서 론}

지방육종은 성인의 연조직 육종에서 악성섬유조직구종 다 음으로 약 $15 \sim 20 \%$ 의 빈도로 흔하지만 ${ }^{1-3)} 60 \%$ 이상에서 하 지 또는 후복막에서 발생하고 두경부 영역에서의 지방육종은 약 $1.8 \sim 6.3 \%^{1,2)}$ 정도로 매우 드물다.

갑상선 결절은 흔히 볼 수 있는 질환으로 성인에서의 발생 빈도는 약 $5 \%$ 전후이며 대부분은 무증상의 종괴이나 그 크 기 및 신경 침윤 정도에 따라 연하 곤란, 호흡 곤란, 목 이물 감, 목소리 변성, 전경부 종괴 등의 다양한 증상을 나타낼 수 있다. ${ }^{4)}$ 기관식도구에 발생할 수 있는 종양으로는 부갑상선 종양, 기관지원성 낭종, 신경성 종양, 림프관종, 새열낭종, 이 소성 흥선종 등이 있을 수 있으며 지방육종이 발생하는 경 우는 매우 드문 것으로 보고되고 있다.5)
저자들은 최근 전경부 종괴를 주소로 내원한 환자에서 여 포상 종양이 의심되는 갑상선 결절로 오인된 기관식도구에 발생한 지방육종 1 예를 경험하였기에 문헌고찰과 함께 보고 하는 바이다.

\section{증 례}

61세 남자 환자로 내원 1개월 전부터 좌측 전경부 종물이 있었으며, 내원 5 일 전에 건강 검진에서 좌측 갑상선에 결절 이 발견되어 본원 내분비내과 방문하여 검사 중 발견된 갑 상선 결절의 수술적 치료를 위해 이비인후과에 의뢰되었다. 환자는 과거력상 5 년 전부터 고혈압으로 약물치료 중이었으 며 그 외 가족력상 특이한 사항은 없었다. 전신 고찰상 좌측 전경부 종물 이외에 인후통, 연하곤란, 호흡곤란, 목의 이 
물감, 목소리 변성, 권태감, 발열 등의 다른 특별한 증상은 없었다. 이학적 검사상 좌측 전경부에 약 $5 \times 4 \mathrm{~cm}$ 크기의 무통 성이며 부드러운 유동성 종물이 관찰되었으며, 촉진되는 경 부 림프절은 없었고, 수술 전 후두내시경검사 소견상 양측 성 대의 움직임은 정상이였으며, 그 외 특이 소견이 없었다. 수술 전에 심전도, 단순 흥부 촬영, 갑상선 기능검사를 포함한 혈액 검사 및 소변검사는 모두 정상 범위였다. 내원 당시 내분비 내 과에서 갑상선 결절 진단을 위해 시행한 갑상선 스캔(Technetium-99 m)검사에서 좌측 갑상선 하방에서 냉결절 소견



Fig. 1. Thyroid scan (Tc-99 m: $4 \mathrm{mCi}$ ). The cold nodule (arrow) in the lower pole of left lobe was noted.



Fig. 2. Neck ultrasonography. The huge heterogenous solid nodule with partially cystic portion (arrow) was located on the posterior portion of left thyroid gland.
을 보였으며(Fig. 1), 경부 초음파검사상 좌측 갑상선에 초음 파 진동자의 범위를 벗어날 정도로 크기가 크고 불균질하며, 낭성 변화 및 혈관분포가 증가된 부분이 포함된 결절이 관찰 되었다(Fig. 2). 경부 초음파하에 세침흡인세포검사를 시행했 으며 여포성 종양 소견을 보였다. 수술적 치료 위해 본과로 전과 되었으며, 경부 전산화단층촬영상 좌측 갑상선의 하방 뒤쪽 에 약 $6 \times 4 \mathrm{~cm}$ 크기의 저밀도 음영과 낭성 변화를 갖는 타원 형의 불균질한 고형의 결절이 관찰되고, 이는 상종격동까지 위 치하였다. 이 결절은 뚜렷한 조영 증강이 되지않으며, 결절에 의 해 좌측 갑상선은 앞쪽으로 전위되고 있었으며 기도는 우측 으로 전위시키는 양상이였으나, 주변 조직으로의 침범은 관찰 되지 않았다(Fig. 3).

이상의 소견으로 갑상선에서 기원한 여포성 종양 혹은 기 관식도구에 발생한 신경원성 종양, 부갑상선 종양, 이소성 흥 선종 또는 심부 연조직 종양 등의 가능성으로 고려하고, 먼저 종양을 포함하여 좌측 갑상선을 절제하여 동결절편 결과를 확인한 후 우측 갑상선 절제술 여부를 고려하기로 하였다. 경 부에 절개를 시행한 후 피대근을 외측으로 견인하자, 좌측 갑 상선의 외측에 피낭 형성이 잘 된 옅은 적황색의 연부 종괴가 관찰되었으며, 종괴와 좌측 반회후두신경의 유착이 심하였고 (Fig. 4), 반회후두신경이 가늘어져 있어 종양과 신경의 구별 이 용이하지 않아 종괴와 함께 반회후두신경을 절제하였다. 술 중 좌측 성대마비에 대한 성대내 주입술이나 후두내전술 등의 술식은 시행하지 않았다. 동결절편검사상 신경원성 종양 이 의심된다고 하여, 배액관 유치 후 수술을 종료하였다. 수 술 후 환자는 애성이 발생했으며, 후두내시경검사상 좌측 진

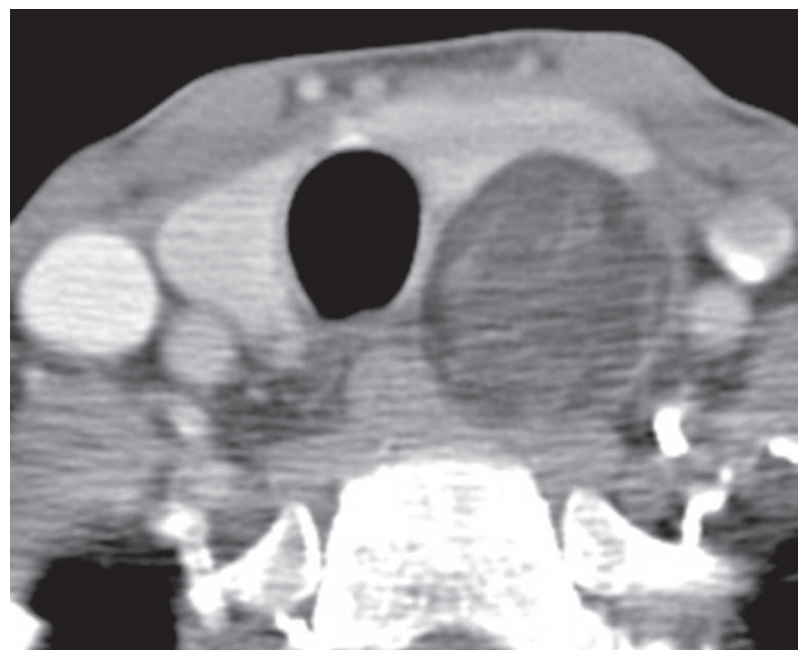

Fig. 3. Preoperative neck CT scan with enhancement. About $6 \times$ $4 \mathrm{~cm}$ sized, heterogenous, solid, well-defined mass was located on the posterior portion of left thyroid gland. It showed non-enhanced and partially low density change. It displaced the left thyroid gland anterioly and the trachea to the right, but had no infiltration into the surrounding tissue. 
Fig. 4. Operative findings. Tumor was located in the left trachoe-esophageal groove. A tight adhesion between the tumor and the left recurrent laryngeal nerve (arrow) was found (A). The specimen was about $6.3 \times 4 \times 2 \mathrm{~cm}$ sized, an ovoid wellencapsulated mass, which was pale redyellowish and soft (B).
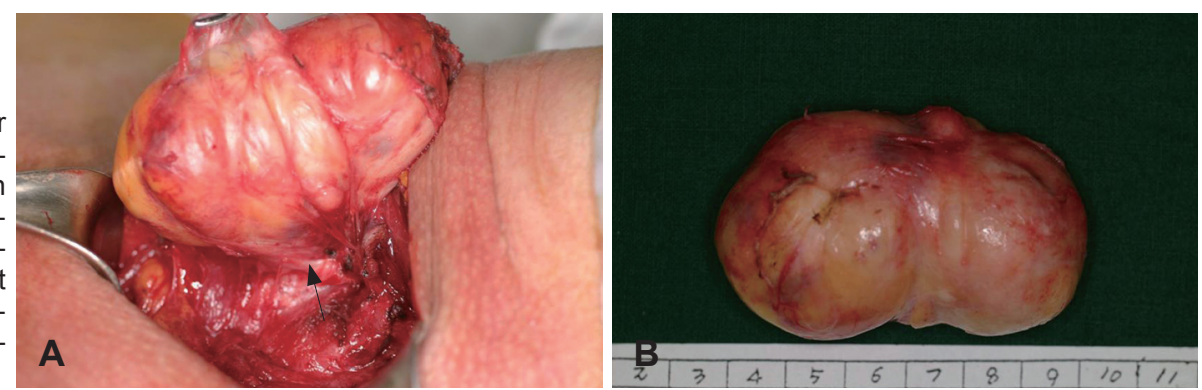

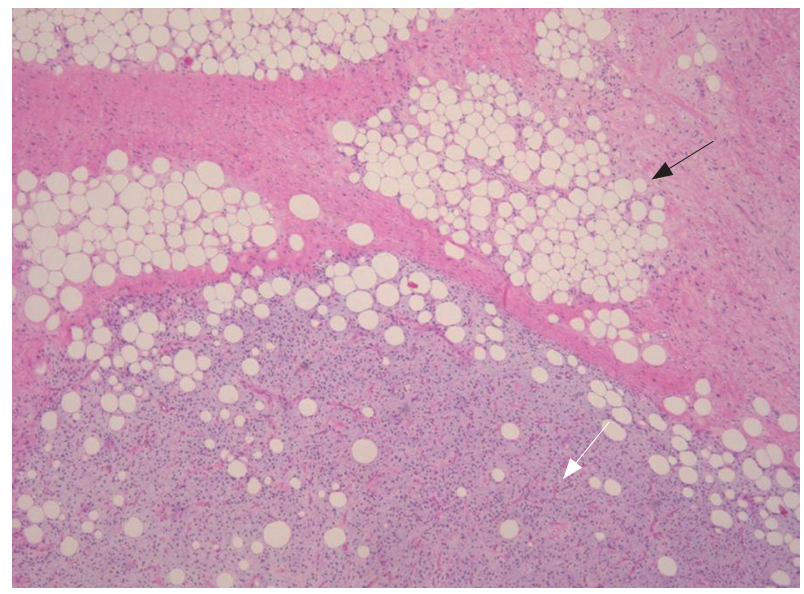

Fig. 5. Microscopic findings $(H \& E \times 40)$. The tumor showed morphological features of well-differentiated liposarcoma (black arrow) that has feature of adipose cells with hyperchromic and bizzare lipoblast and myxoid liposarcoma (white arrow) that has monomorphic fusiform cells in a mucoid stroma with a plexiform capillary network. The boundary had an indistinct margin between them.

성대는 부정중 고정 소견을 보였으며 그 외 특이 소견은 보이지 않았다. 적출된 종괴의 크기는 약 $6.3 \times 4 \times 2 \mathrm{~cm}$ (Fig. 4)로 병 리 조직학적 소견은 고분화 지방육종과 점액성 지방육종이 섞여 있는 혼합형 지방육종이었다(Fig. 5). 수술 후 전신전이 여 부 확인을 위해 양자 방출 전산화단층촬영을 시행했으며 전 이가 없음을 확인하였다. 수술 1 개월 후 좌측 성대에 대한 주 입 후두성형술 시행하였고, 수술 1 개월 후부터 방사선 치료를 33 회(총 5,490 cGy) 시행 받았으며, 현재 술 후 36개월째로 재발 및 전이 소견 없이 외래 경과관찰 중이다.

\section{고 찰}

지방육종은 1857 년에 $\operatorname{Virchow}^{6}$ 에 의해 처음 보고되었다. 이 종양은 지방종보다 빈도가 100배 드물고, 지방종이 피하 조직에서 발생하는 것과는 다르게 심부 연조직에서 발생한 다. 지방육종은 성인의 연조직 육종에서 악성섬유조직구종 다음으로 흔하며 ${ }^{1-3)}$ 대개 50 60대의 성인에서 발병하고 ${ }^{3-8)}$ 발생하는 위치는 체간(특히 후복막) $-42 \%$, 하지 $-41 \%$, 상지$11 \%$, 두경부-1.8-6.3\% 순이다. ${ }^{1,3)}$ 특히, 두경부에서 발생하
는 지방육종은 평균적으로 40 대의 남성에서 흔한 것으로 보고 되고 있으며, ${ }^{9)}$ 그 위치는 구강 협부- $14 \%$, 전경부- $13 \%$, 후두 $-13 \%$, 안와-8\%, 성문상부-7\% 순이다. ${ }^{9)}$ 임상적으로 지방육종 은 천천히 증대되고 초기 증상은 없는 경우가 많지만, 가끔씩 빠르게 증대되어 두경부 종괴, 연하곤란, 목소리 변성, 호흡 곤 란, 목의 이물감 등의 증상을 나타내는 경우도 있다. ${ }^{2}$ 지방육종 은 병리조직학적으로 고분화 유형(well-differenciated), 점액 성 유형(myxoid), 다형성 유형(pleomorphic) 및 원형세포 유 형(round cell)의 네 유형으로 분류하고 ${ }^{2,3,10,11)}$ 빈도는 점액성 유형(30 50\%), 고분화 유형(20 30\%), 다형성 유형(10 25\%), 원형세포 유형(10 15\%) 순이다. ${ }^{3)}$ 점액성 유형은 국소재발은 흔 하나 원격전이가 드물어 5 년 생존율이 $75 \sim 100 \%$ 이다. ${ }^{1-3,12)}$ 고분 화 유형도 점액성 유형과 마찬가지로 국소 재발은 흔하나 원격 전이가 드물어 5년 생존율이 75 100\%이며, 경화지방육종과 지 방종양 지방육종의 아형이 있다.,7-9) 다형성 유형과 원형세포 유형은 국소 침윤 및 국소 재발과 원격 전이가 흔하여 5년 생 존율이 $20 \%$ 미만이다. ${ }^{2,7,9,12)}$ 두경부에 발생하는 지방육종의 치료는 완전한 수술적 적출법이다. ${ }^{2,3,11,13)}$ 두경부의 지방육종은 중요 구조물과 근접해 있어 완전한 적출이 어려울 수도 있으 며, 이러한 경우에는 국소재발률을 증가시키고 5년 생존율을 감 소시킬 수도 있다. ${ }^{2,311)}$ 대부분의 두경부의 지방육종은 술 전 또는 술 후에 방사선 치료를 동반하게 되며, 이는 국소재발률 을 감소시키고 5년 생존율을 증가시킬 수 있다. 특히 점액성 유 형은 방사선 치료에 민감하여 반드시 방사선 조사를 시행하는 것으로 보고된다. ${ }^{211,14)}$ 두경부 지방육종의 경우 갑상선에서 발생 하는 원발성 지방육종은 극히 드물게 보고되고 있으며 갑상 선의 원발성 지방육종의 치료는 갑상선 전적출술이며, 림프절 전이가 있으면 경부 곽청술을 시행해야 한다. ${ }^{15)}$ 육안적으로 지 방육종의 완전히 적출이 가능하면 추후의 갑상선 전적출술을 시행할 필요는 없는 것으로 보고된다. ${ }^{3)}$ 방사선에 민감한 경우, 분화도가 낮은 경우, 크기가 큰 경우, 수술적으로 완전한 절제 가 불가능한 경우는 추가적으로 반드시 방사선 조사를 시행하 여야 한다. ${ }^{11)}$ 추가적인 항암치료의 유용성은 원격 전이가 있 는 경우를 제외하고는 아직까지 증명되지 않았다. ${ }^{2,3}$

본 증례에서는 갑상선의 여포성 종양 의심하에 수술을 시 
행하였으나 갑상선의 원발성 종양이 아닌 기관식도구에 발생 한 지방육종으로 확인된 사례로 술 중 육안적으로 완전한 적 출이 가능하였기에 추후의 갑상선 전적출술은 시행하지 않았 으며, 크기가 크고 방사선에 민감한 유형의 지방육종으로 진 단되어 방사선 치료를 추가로 시행하였고 현재 재발 소견 없 이 경과 관찰 중이다. 본원에서는 반회후두신경의 절제가 확 실한 경우에도 즉각적인 성대내 주입술이나 후두내전술 등은 시행하지 않고 술 후 경과를 관찰하여 성대 위치를 확인 후 필요한 경우에 추가적인 치료를 시행하는 원칙을 따르고 있어 본 증례의 경우에도 수술 시 특별한 조치는 취하지 않았다.

두경부에 발생하는 지방육종은 드문 것으로 되어 있으며 그 중 기관식도구 및 갑상선에 발생한 경우는 매우 드문 것으 로 되어 있다. 저자들은 갑상선 결절 및 여포성 종양으로 오 인된 기관식도구에 발생한 지방육종을 경험하였기에 임상적 특징 및 수술적 경험을 문헌고찰과 함께 보고하는 바이다.

\section{REFERENCES}

1) Davis EC, Ballo MT, Luna MA, Patel SR, Roberts DB, Nong X, et al. Liposarcoma of the head and neck: The University of Texas M. D. Anderson Cancer Center experience. Head Neck 2009;31(1):2836.

2) Demir D, Katircioglu S, Suoglu Y, Bilgic B. Radiation-induced liposarcoma of the retropharyngeal space. Otolaryngol Head Neck Surg 2006;134(6):1060-2.
3) Mitra A, Fisher C, Rhys-Evans P, Harmer C. Liposarcoma of the thyroid. Sarcoma 2004;8(2-3):91-6.

4) Yeung MJ, Serpell JW. Management of the solitary thyroid nodule. Oncologist 2008;13(2):105-12.

5) Newkirk KA, Tassler AB, Krowiak EJ, Deeb ZE. Bronchogenic cysts of the neck in adults. Ann Otol Rhinol Laryngol 2004;113(9): 691-5.

6) Virchow R. Einfall von bosartigen, zum theil in der form des neurons auftrtenden fettgeschwullsten. Virchows Arch A Pathol Anat Histopathol 1857;11:281-8.

7) Azar AR, Weynand B, Daumerie C, Coche E. Metastatic liposarcoma of the thyroid gland. Br J Radiol 2003;76(910):750-2.

8) Kyriakos M. Pathology of selected soft tissue tumors of the head and neck. In: Thawley SE, Panje WR, Batsakis JG, Lindberg RD, editors. Comprehensive Management of Head and Neck Tumors. Philadelphia, Pa: WB Saunders Co;1987. p.1254-6.

9) Yueh B, Bassewitz HL, Eisele DW. Retropharyngeal liposarcoma. Am J Otolaryngol 1995;16(5):331-40.

10) Stout AP. Liposarcoma-The malignant tumor of lipoblasts. Ann Surg 1944;119:86-107.

11) Casani AP, Marchetti M, Dallan I, Cagno MC, Berrettini S. Liposarcoma of the cervico-nuchal region. Otolaryngol Head Neck Surg 2005;133(4):641.

12) Golledge J, Fisher C, Rhys-Evans PH. Head and neck liposarcoma. Cancer 1995;76(6):1051-8.

13) Enzinger FM, Weiss SW. Liposarcoma. Soft Tissue Tumors. $2^{\text {nd }}$ ed. St Louis: CV Mosby;1988. p.346-82.

14) Eeles RA, Fisher C, A'Hern RP, Robinson M, Rhys-Evans P, Henk $\mathrm{JM}$, et al. Head and neck sarcomas: prognostic factors and implications for treatment. Br J Cancer 1993;68(1):201-7.

15) Sniezek JC, Holtel M. Rare tumors of the thyroid gland. Otolaryngol Clin North Am 2003;36(1):107-15. 